\title{
Magdalena LORENC
}

Uniwersytet im. Adama Mickiewicza, Poznań

\section{Formy eskalacji sprzeczności w stosunkach międzynarodowych - analiza pojęciowa}

$W_{\text {nia się interesów narodowych i państwowych. Potrzeby leżące }}^{\text {spółczesne stosunki międzynarodowe saren bezustannego ściera- }}$ u podstaw definiowania owych interesów, mogą mieć obiektywny lub subiektywny charakter. Niezależnie od klasyfikacji potrzeb, rzeczą konieczną jest możliwość ich artykulacji, związana z obecnością innych podmiotów na arenie międzynarodowej. Państwa, jako pierwotne podmioty prawa międzynarodowego, nie funkcjonują w próżni, lecz stanowią podstawowe elementy systemu międzynarodowego ${ }^{1}$. Charakter aktywności państw w sferze stosunków międzynarodowych jest zatem wiodącym czynnikiem zmian i ich instytucjonalizacji w obrębie danego systemu. U podstaw działalności państw leży określony zespół czynników, których analiza pozwala na diagnoze ,motywacji rzeczywistych” i „motywacji deklarowanych" polityki zagranicznej ${ }^{2}$. Ukierunkowany na zewnątrz wysiłek państw zmierza, pod postacią polityki zagranicznej, do kreowania i wykorzystywania okoliczności sprzyjających realizacji interesu narodowego (rozumianego jako zespół celów i potrzeb państwa i narodu) ${ }^{3}$. Państwo wykazując aktywność w sferze polityki zagranicznej, koncentruje uwagę nie tylko na celach, lecz głównie na instrumentach ich realiza$\mathrm{cji}^{4}$. Oddziaływanie w środowisku międzynarodowym powoduje określo-

${ }^{1}$ Por. J. Kukułka, Problemy teorii stosunków międzynarodowych, Warszawa 1978, s. 173 i n.

2 Szerzej na temat motywów polityki zagranicznej w: J. Stefanowicz, Motywy polityki zagranicznej, „Sprawy Międzynarodowe” 1980, z. 10, s. 97-108.

${ }^{3}$ Por. R. Kuźniar, Międzynarodowe stosunki polityczne, w: Stosunki międzynarodowe. Geneza, struktura, dynamika, pod red. E. Haliżaka, R. Kuźniara, Warszawa 2001, s. 112; J. Z. Pietraś, Polityka zagraniczna państwa, w: Wspótczesne stosunki międzynarodowe, pod red. T. Łoś-Nowak, Wrocław 1997, s. 51-54; T. Łoś-Nowak, Interesy narodowe i międzynarodowe, w: Wspótczesne..., s. 68.

${ }^{4}$ Por. J. Kukułka, Polityka zagraniczna jako element procesu oddziaływań międzynarodowych, w: Zmienność i instytucjonalizacja stosunków międzynarodowych, 
ne interakcje ze strony pozostałych członków społeczności międzynarodowej. Z drugiej zaś strony, podmiot działania przeistacza się w przedmiot aktywności innych elementów środowiska międzynarodowego. Współzależność stanowi zatem determinantę trwałości, jak również zmiany w systemie międzynarodowym.

Rosnąca rola działań i oddziaływań decyduje o wzroście intensywności postulowanych przez podmioty prawa międzynarodowego zmian. Powyższe jest wyznacznikiem narastających sprzeczności oraz towarzyszących im napięć w stosunkach międzynarodowych. Skala dysproporcji i możliwość ewentualnej jej niwelacji, są w znacznej mierze uzależnione od stopnia korelacji interesów między antagonistami oraz ich determinacji. Trudności, a niejednokrotnie brak rzeczywistych chęci w przezwyciężaniu sprzeczności, powodują eskalację napięcia i radykalizację stanowisk. Konsekwencją takiego stanu rzeczy jest ewoluowanie sprzeczności w kierunku sporu, konfliktu lub kryzysu. Wspomniane wyszczególnienie nie jest jednak satysfakcjonujące, bowiem nie uwzględnia zjawisk patologicznych, w dobie delegalizacji ius ad bellum (prawo do wojny), w których sprzeczności przyjmują postać konfliktu zbrojnego. Powyższe stany ewolucji sprzeczności i napięć międzynarodowych nie mają charakteru liniowego, choć niekiedy społeczność międzynarodowa jest świadkiem przeistaczania się sporu w konflikt, konfliktu w kryzys, kryzysu zaś w wojnę. Ostateczny wybór „drogi” nie jest efektem automatycznego przechodzenia z jednego stadium w drugie, lecz wyrazem racjonalnych wyborów, których autorzy świadomi są następstw podejmowanych decyzji. W związku z powyższym nie każdy spór, na skutek wzrostu napięcia i w obliczu narastających sprzeczności, ulegnie transformacji w kierunku kryzysu międzynarodowego, podobnie jak nie każdy kryzys przerodzi się $\mathrm{w}$ wojnę. Z drugiej strony, nieuprawnione w przypadku sporów, konfliktów, kryzysów i konfliktów zbrojnych, stosowanie porządku liniowego, jest uzasadnionym narzędziem naukowej refleksji nad fazami zmienności sprzeczności w stosunkach międzynarodowych ${ }^{5}$. Uogólniając, możemy za Józefem Kukułką wskazać trzy fazy, ważne z perspektywy analizy omawianych zjawisk: pierwszą - zarysowywania, drugą - zaostrzania, trzecią

pod red. J. Kukułki, Warszawa 1988, s. 151-158; R. Kuźniar, Międzynarodowe stosunki polityczne, w: Stosunki..., s. 116-117.

${ }_{5}$ Por. J. Kukułka, Zaspokajanie potrzeb i rozwiazywanie konfliktów w stosunkach międzynarodowych, w: Stosunki..., s. 246. 
- rozwiązania sprzeczności ${ }^{6}$. Wymienione kategorie: spór, konflikt, kryzys i konflikt zbrojny są właściwe dla drugiej fazy - fazy zaostrzania sprzeczności, w której środki dyplomatycznej perswazji wielokrotnie kończą się fiaskiem, a różnice stanowisk utrwalają stan impasu w stosunkach między stronami. Złożoność i różnorodność praw rządzących środowiskiem międzynarodowym zmusza do stwierdzenia, iż niektóre formy sprzeczności, które znalazły się w fazie drugiej, z różnych względów nie osiągają stadium rozwiązania. Nie wynika to jednak z permanentnej niemożności przezwyciężenia sprzeczności (nawet przy hipotetycznym wyczerpaniu dostępnych środków), lecz z uwarunkowań międzynarodowych i wewnątrzpaństwowych oraz utrwalonego w świadomości uczestników stosunków międzynarodowych, braku możliwości regulacji. Poczucie bezsilności i swoiste tolerowanie przez innych członków społeczności międzynarodowej, trwałego stadium zaostrzonych sprzeczności, stanowi przesłankę negatywnie wpływającą na perspektywy definitywnego zażegnania napięcia, odraczając ten proces w czasie.

Mówiąc o sprzecznościach i napięciach w stosunkach międzynarodowych, traktujemy je jako domenę wszelkich stosunków społecznych, będących nieodłącznym elementem prób artykulacji potrzeb. Powstawanie sprzeczności, definiowanej jako różnica interesów, potrzeb i wartości, jest procesem naturalnym dla wielopodmiotowego systemu międzynarodowego ${ }^{7}$. Specyfika zagrożeń związanych z występowaniem sprzeczności jest w przeważającej mierze pochodną labilności form rozwojowych tego zjawiska, aniżeli samego faktu jego występowania. Jest to o tyle znaczące, o ile dobór sposobów regulacji sprzeczności, jest warunkowany etapem jej ewolucji.

Biorąc pod uwagę konsekwencje, jakie dla trwałości i zmiany w systemie międzynarodowym ma wzrost napięć między jego elementami, rzeczą konieczną jest zdefiniowanie stanów eskalacji sprzeczności.

Zasadniczy problem w analizie przejawów zaostrzania sprzeczności w stosunkach międzynarodowych warunkowany jest brakiem norm prawnych je definiujących. Trudności wynikające z nieobecności wyczerpujących uregulowań prawnych nie stanowiąjednak satysfakcjonującego uzasadnienia dla niemożności prowadzenia rozważań nad istotą omawia-

6 J. Kukułka, Dialektyka sprzeczności i napięć w stosunkach międzynarodowych, w: Zmienność..., s. 13.

7 Por. R. Zięba, Wojskowe aspekty napięć międzynarodowych, w: Zmienność..., s. 189. 
nych zjawisk. Zasadnicze problemy w tworzeniu powszechnie akceptowanych definicji tkwią, między innymi, w zamiennym traktowaniu pojęć „spór”, „konflikt”, „kryzys”, i to nie tylko w publicystyce, lecz również w opracowaniach o charakterze naukowym. Traktowanie powyższych terminów jako synonimów jest praktyką naganną i w żadnej mierze nieuprawnioną.

Celem poniższych rozważań będzie wykazanie elementów zbieżnych, lecz przede wszystkim dyferencji leżącej u podstaw rozłącznego traktowania tych kategorii. Postawa pragmatyczna decyduje o konieczności uwzględnienia nie tylko legalnych (tj. zgodnych z pozytywnym prawem międzynarodowym) zjawisk, takich jak spór i konflikt, lecz również środków nielegalnych, tożsamych z konfliktem zbrojnym. Uzasadnionym zabiegiem, biorąc pod uwagę argument przejrzystości, będzie rozpatrywanie eskalacji sprzeczności w porządku pierwszeństwa form łagodniejszych, a na radykalnych kończąc.

Pod pojęciem „sporów międzynarodowych” doktryna prawa międzynarodowego publicznego rozumie, występowanie sprzeczności między uczestnikami stosunków międzynarodowych ${ }^{8}$. Równocześnie brak norm publicznego prawa międzynarodowego, definiujących pojęcie sporu, tworzy sposobność dla podejmowania wysiłków o charakterze głównie opisowym, nie zaś definicyjnym. Znakomita większość analiz pojęciowych dotyczy wyłącznie sporów między państwami i również poniższe uwagi będą nań skoncentrowane?

Specyfika i różnorodność sprzeczności, determinują charakter i istotę sporów międzynarodowych. Podstawą każdego sporu, niezależnie od stopnia jego natężenia, jest wyraźna (nigdy nie domniemana) wola stron, wyrażona $\mathrm{w}$ danym stanowisku, a określana mianem ,przedmiotu sporu"10. Powstanie sytuacji spornej jest konsekwencją roszczeniowego charakteru żądań jednej strony pod adresem drugiej, która z kolei odmawia spełnienia przedstawionych warunków. Żądanie podmiotu prawno-międzynarodowego lub grupy takich podmiotów ma na celu wymuszenie

8 Por. W. Malendowski, Spory i konflikty międzynarodowe, w: Międzynarodowe stosunki polityczne, pod red. W. Malendowskiego, Cz. Mojsiewicza, Poznań 1997, s. 355 .

9 A. Klafkowski, Prawo międzynarodowe publiczne, Warszawa 1979, s. 378 i n.; L. Antonowicz, Podręcznik prawa międzynarodowego, Warszawa 2002, s. 214.

10 M. Iwanejko, Spory międzynarodowe. Studium prawno-polityczne, Warszawa 1976, s. 25 . 
określonego zachowania (działania, zaniechania działania lub znoszenia), na innym uczestniku bądź uczestnikach stosunków międzynarodowych ${ }^{11}$. Siła prezentacji owych żądań uzależniona jest od źródeł sprzeczności oraz od organów decydenckich, odpowiedzialnych za politykę zagraniczną. Zasadnicza przyczyna powstawania sporów międzynarodowych tkwi w sposobach pojmowania interesu narodowego i państwowego oraz środkach (zgodnych lub niezgodnych z prawem) ich ochrony ${ }^{12}$. Geneza i istota sprzeczności jest ważna z punktu widzenia stopnia zagrożenia, jakie dany spór niesie dla pokoju i bezpieczeństwa międzynarodowego. Istota refleksji teoretycznej dotyczy w przeważającej mierze sporów, które w „sprzyjających" okolicznościach, grożą ewoluowaniem w kierunku konfliktów zbrojnych. Zasadnicza część sporów nie ulega powyższemu procesowi przemian i po stadium wzmożonego natężenia, poddawana jest stopniowemu ograniczaniu lub likwidacji sprzeczności. Clou sprzeczności, w tym ostatnim przypadku, nie jest jednak determinowane kategoriami „racji stanu", gdyż wówczas wszelki kompromis byłby tożsamy ze sprzeniewierzeniem się dobru państwa ${ }^{13}$. Stosowanie enigmatycznego terminu ,racji stanu" i swoboda w definiowaniu jej istoty, stanowi niebezpieczne narzędzie w rękach populistycznych polityków, zwłaszcza z perspektywy eskalacji sporów międzynarodowych. Gros sporów, które potraktowane zostały jako zagrożenie dla fundamentalnych i bezkompromisowych interesów państwa i narodu, dowiodło prawidłowości wpływu argumentu ,racji stanu" na radykalizację stanowisk i niemożności przełamania impasu w stosunkach między stronami.

Problemy związane z definiowaniem sporów międzynarodowych, dodatkowo powodowane są, różnorodnością zamieszczanych w umowach międzynarodowych określeń: „spór”, „sytuacja”, „kwestia”, „,konflikt”, „różnica” itp. ${ }^{14}$ Przykładem takiej praktyki traktatowej jest Karta Narodów Zjednoczonych (dalej Karta NZ), która wśród celów Organizacji Narodów Zjednoczonych (dalej ONZ) w art. 1, sygnalizuje konieczność

11 Ibidem.

12 Por. L. Ehrlich, Prawo międzynarodowe, Warszawa 1958, s. 356.

13 Szerzej na temat ,racji stanu” i kategorii pokrewnych, m.in. w: T. Łoś-Nowak, Interesy narodowe i międzynarodowe, w: Wspótczesne..., s. 74; Interesy narodowe a współdziałanie państw, pod red. J. Z. Pietrasia, M. Pietraś, Lublin 1990, passim; J. Stefanowicz, Motywy..., s. 97-100.

14 R. Bierzanek, Załatwianie sporów międzynarodowych 1945-1973. Studium prawno-międzynarodowe, Warszawa 1974, s. 12. 
„łagodzenia i załatwiania - w drodze pokojowej, według zasad sprawiedliwości i prawa międzynarodowego - sporów lub sytuacji mogących prowadzić do naruszenia pokoju"15. Zaprezentowana forma zestawienia pojęć „sporów lub sytuacji”, oznacza alternatywne ujęcie owych zjawisk. Termin „sytuacja” jest materią trudniej poddającą się konkretyzacji, aniżeli pojęcie „spór”, gdyż w rozumieniu Karty NZ jest kategorią szerszą. Egzemplifikacje powyższego znaleźć można w art. 14, zalecającym „sposoby pokojowego załatwiania wszelkich sytuacji, bez względu na źródło ich powstania, które, [...] mogą zaszkodzić powszechnemu dobru lub przyjaznym stosunkom między narodami, [...]”. Pewnym ułatwieniem może być w tym względzie art. 34 Karty NZ, w rozumieniu którego ,sytuacja” to stan, „który może doprowadzić do nieporozumień międzynarodowych lub wywołać spór”. Adekwatną interpretacją „sytuacji”, będzie traktowanie jej jako stanu rzeczy, który może zagrozić pokojowi, przy równoczesnym braku roszczeń wzajemnych, właściwych dla sporu ${ }^{16}$. „Spór” jest zatem stanem dużo bardziej czytelnym dla otoczenia międzynarodowego, niż „sytuacja”, gdyż zakłada nie tylko istnienie stron, lecz również sprecyzowanych żądań przez nie artykułowanych. Rozróżnienie kategorii „sporów” i ,sytuacji” ma w rozumieniu Karty NZ charakter zdecydowanie praktyczny, zwłaszcza w odniesieniu do kompetencji Rady Bezpieczeństwa Narodów Zjednoczonych (dalej Rady Bezpieczeństwa NZ). Zgodnie z art. 27 ust. 3 Karty NZ w odniesieniu do głosowań, w Radzie Bezpieczeństwa NZ, ,przy podejmowaniu decyzji [...] strona w sporze wstrzymuje się od głosu". Tymczasem w przypadku zakwalifikowania zdarzenia jako „sytuacji mogącej prowadzić do naruszenia pokoju”, kompetencje decyzyjne członków nie ulegają żadnym ograniczeniom, nawet w sytuacji bezpośredniego zaangażowania. Brak możliwości uchwycenia dyferencji między pojęciem „spór” i „sytuacja”, w treści artykułów Karty NZ, niesie niebezpieczeństwo względnego i subiektywnego wyboru danej opcji przez członków Rady Bezpieczeństwa NZ, w zależności od okoliczności i zapotrzebowań.

Charakter pomocniczy, na drodze do wyjaśnienia „czym jest spór?”, mają wyroki i opinie doradcze oraz uregulowania statutowe Stałego Try-

15 Cyt. z Karty NZ za przekładem urzędowym, w: Dziennik Ustaw (dalej Dz. U.) 1947, nr 23, poz. 90.

16 L. Goodrich, E. Hambro, Charter of the United Nations. Commentary and Documents, Boston 1946, s. 149, podaję za: J. Sutor, Klasyfikacja sporów międzynarodowych, „Państwo i Prawo” 1975, z. 6, s. 56. 
bunału Sprawiedliwości Międzynarodowej (dalej STSM), jak również Międzynarodowego Trybunału Sprawiedliwości (dalej MTS). Szczególnie interesujący z punktu widzenia omawianych zagadnień i jednocześnie wielokrotnie przytaczany w literaturze przedmiotu, wyrok kompetencyjny STSM z 30 sierpnia 1924 r. w sprawie palestyńskich koncesji Mavrommatisa, pod pojęciem spór rozumie: ,różnicę stanowisk odnośnie do elementów prawa lub faktów, konflikt poglądów prawnych lub interesów między dwoma osobami" "17. Dopełnieniem rozważań będzie treść opinii doradczej MTS z dnia 30 marca 1950 r. w sprawie interpretacji traktatów pokojowych z Bułgarią, Węgrami i Rumunią, gdzie spór oznacza „sytuację, w której punkty widzenia dwóch stron są wyraźnie przeciwstawne" 18 .

Podsumowując, ,spór” (międzynarodowy), jest to taki stan rzeczy w którym występują ściśle określeni, silnie spolaryzowani aktorzy. Aktywność podmiotu lub grupy podmiotów $\mathrm{X}$ godzi w szeroko rozumiane interesy narodowe i państwowe podmiotu, lub grupy podmiotów Y. Działania stron mają charakter werbalny i ograniczają się wyłącznie do mniej lub bardziej ostrych wystąpień. Źródłem sporów jest powstanie sprzeczności, która z czasem ulega uściśleniu, przyjmując postać sprecyzowanych żądań pod adresem drugiej strony. Radykalizacja form wystapień podmiotu X napotyka na wzmożony opór podmiotu Y, powodując kostnienie niekorzystnego stanu relacji. Podstawą zaistnienia sporu jest zatem postawa roszczeniowa, poparta normami prawa międzynarodowego lub funkcjonująca wbrew im. Znakomita większość sporów poddaje się również regulacji w oparciu o dostępne środki prawne ${ }^{19}$.

Pojęciem niegdyś chętnie przytaczanym, a związanym również ze stanem sprzeczności, był termin „kwestia”, który znalazł zastosowanie m.in. w art. 14 Paktu Ligi Narodów (dalej Pakt LN). Ponieważ jego obecność, między innymi, w ujęciach traktatowych, stanowiących podstawę funkcjonowania organizacji międzynarodowych o charakterze uniwersalnym, nie znalazła potwierdzenia w okresie późniejszym, nie będzie on przedmiotem niniejszych rozważań.

17 Permanent Court of International Justice (dalej PCIJ), Collection of Judgements (1922-1930), seria A, s. 11.

18 Cyt. za: R. Bierzanek, op. cit., s. 11.

19 Por. Mały słownik stosunków międzynarodowych, pod red. G. Michałowskiej, Warszawa 1996, s. 221. 
Obok „,sporu”, obecnie równie popularny, jest termin „konflikt”. Konflikt (od łacińskiego słowa conflictus - zderzenie), analogicznie jak spór, jest następstwem sprzeczności, mającej źródło w różnicy interesów, między zaangażowanymi stronami. Sprzeczności interesów są domeną zarówno stosunków wewnątrzpaństwowych, jak i stosunków międzynarodowych, w związku z czym wyróżniamy konflikty wewnątrzpaństwowe i konflikty międzynarodowe.

Szereg heterogenicznych refleksji w przedmiocie konfliktów międzynarodowych nie sprzyjał i nadal nie sprzyja, stworzeniu jednolitej, powszechnie akceptowanej analizy teoretycznej, dotyczącej istoty omawianego fenomenu. Kierunki rozważań skoncentrowane są, z jednej strony, na poszukiwaniu analogii między konfliktami międzynarodowymi a innymi konfliktami społecznymi, z drugiej zaś, na dowodzeniu ich odrębności.

Wzajemne przenikanie się konfliktów wewnątrzpaństwowych i konfliktów międzynarodowych oraz występowanie cech wspólnych, im właściwych, czyni nieuzasadnionym traktowanie wspomnianych konfliktów, jako odrębnych zjawisk ${ }^{20}$. Powyższe ujęcie, oparte na traktowaniu konfliktów międzynarodowych, jako subkategorii konfliktów społecznych, potwierdza naturalność występowania konfliktów na wszystkich płaszczyznach stosunków społecznych ${ }^{21}$. Postrzeganie konfliktów, nie przez pryzmat sytuacji patologicznych, lecz właściwych i koniecznych, tworzy przesłankę do analizy podstaw takiej oceny. U źródeł konfliktów leżą określone sprzeczności interesów, które mogą mieć rzeczywisty lub surrealistyczny charakter. Powstanie sytuacji konfliktowej, często nie jest następstwem obiektywnych sprzeczności interesów, lecz subiektywnych wyobrażeń o ich istnieniu. Dopiero uświadomienie sprzeczności, a nie sam fakt jej funkcjonowania, determinuje określone zachowania organów decyzyjnych. Subiektywne wystąpienie sprzeczności jest pochodną kreatywności i zapotrzebowań środowiska władzy. Nie oznacza to jednak całkowitego braku obiektywnych przesłanek sprzeczności interesów, a jedynie pojmowania ich w kategoriach drugorzędnych. Przyznanie prymatu uwarunkowaniom nierzeczywistym, pozwala na jednostronne zażegnanie konfliktu, drogą przedefiniowania pojęć składających się na sprzeczności.

20 Por. S. Bieleń, Brytyjska nauka o stosunkach międzynarodowych, Warszawa 1986, s. $165-169$.

21 Ibidem, s. 165. 
Relatywność kategorii ,interesów”, dopuszcza dostosowywanie jej do politycznego dyskursu ekip rządzących. To co w danym czasie uznane zostanie za podstawowy interes państwa i narodu, może w zależności od okoliczności, zostać odmiennie zaklasyfikowane. Miejsce interesów, stanowiących źródło sprzeczności, a następnie konfliktów, jest zasadnicze z punktu widzenia sposobów i siły ich artykulacji. Zgodnie z powyższymi rozważaniami, należy stwierdzić iż przyczyna konfliktów tkwi w pojmowaniu sytuacji, niekoniecznie posiadającej walor rzeczywisty. Konflikt międzynarodowy stanowi zatem konsekwencję, świadomych decyzji w polityce wewnętrznej.

Zagadnienie świadomości, jako podstawy zachowań racjonalnych w sferze polityki jest problemem kluczowym przy wykorzystaniu ,teorii gier”, w badaniach nad konfliktami międzynarodowymi. Wówczas bowiem warunkiem podstawowym jest założenie, zgodnie z którym decyzje podejmowane w sytuacjach konfliktowych, mają na celu maksymalizację korzyści, przy założeniu, że wszystkie strony postępują racjonalnie ${ }^{22}$. Świadome zastosowanie dostępnych metod i środków, składające się na działanie polityczne, zmierza do niepodzielnego zwycięstwa jednej strony i klęski drugiej, dając „grę o sumie zerowej”. Sytuacja konfliktowa, przy braku woli kompromisu, może zostać zażegnana jedynie zwycięstwem i przegraną zaangażowanych stron.

Powyższym rozważaniom, wypada przeciwstawić refleksje dowodzące konieczności rozłącznego traktowania pojęć „konflikt wewnątrzpaństwowy” i „konflikt międzynarodowy”. Dychotomiczne pojmowanie tych dwóch kategorii koncentruje się na dominacji elementów rozbieżnych, decydujących o specyfice i niepowtarzalności konfliktów reprezentatywnych dla różnych płaszczyzn stosunków społecznych. Konflikt, zgodnie z powyższymi warunkami, jest stanem obiektywnie występujących sprzeczności. Mimo, iż jest sytuacją normalną, nie jest stanem permanentnym, właściwym stosunkom międzynarodowym. Interesy państw i narodów są bowiem wówczas sprzeczne i stanowią przyczynę konfliktów, gdy zagrażają podstawowym potrzebom aktorów międzynarodowych, a zwłaszcza potrzebie bezpieczeństwa. Zarysowanie sytuacji konfliktowej, nie jest uzależnione od stopnia świadomości organów władczych w materii faktu, jak również nie jest nią warunkowane. Wszelka analiza sku-

22 Leksykon politologii, pod red. A. Antoszewskiego, R. Herbuta, Wrocław 1996, s. 112. 
piona jest zatem na badaniu przesłanek rzeczywistych, zasadniczo różnych w przypadku konfliktów wewnątrzpaństwowych i międzynarodowych.

Abstrahując od zasadności łącznego lub rozłącznego pojmowania konfliktów wewnątrzpaństwowych i międzynarodowych, niejednokrotnie mamy do czynienia $\mathrm{z}$ procesem umiędzynarodawiania konfliktów wewnątrzpaństwowych. Powyższemu procesowi towarzyszy szereg uwarunkowań związanych z zaangażowaniem państw trzecich, a mających charakter wspomagający. Składa się nań wszelkie wsparcie materialne, obejmujące pomoc finansową, dostawy sprzętu wojskowego czy tworzenie zaplecza logistycznego, jak również wywieranie nacisku środkami dyplomatycznymi, wysyłanie doradców i stopniowe ograniczenie samodzielności procesu decyzyjnego w obrębie organów władzy danego państwa $^{23}$. Przyjmując wspomniane mechanizmy, konflikt wewnętrzny jest stadium poprzedzającym konflikt międzynarodowy. Należy zauważyć, iż mamy również do czynienia z sytuacją odwrotna, w której konflikt międzynarodowy nie pozostaje bez wpływu na konflikt wewnętrzny. Nie należy przez to rozumieć, iż konflikt wewnętrzny jest następstwem konfliktu międzynarodowego, a jedynie, że te dwie formy konfliktów mogą się wzajemnie implikować.

Konflikt międzynarodowy oznacza taki stan rzeczy, w którym uświadomione interesy zaangażowanych stron, wzajemnie się wykluczają. Różnica między sporem a konfliktem nie sprowadza się wyłącznie do intensyfikacji zagrożeń i radykalizacji postaw, wynikających z obrony interesów, lecz również z zasięgu konfliktu międzynarodowego. Zestawiając spory i konflikty międzynarodowe, zasięg tych drugich jest nieporównywalnie szerszy i angażuje szereg płaszczyzn społecznych. Nie pozostaje również niezauważonym dla innych uczestników stosunków międzynarodowych, niosąc niebezpieczeństwo użycia siły militarnej i zagrożenia dla pokoju. Konflikt międzynarodowy może mieć dwojaki charakter. Po pierwsze może, ograniczyć się do „konfliktu werbalnego”, polegającego na stosowaniu gróźb, ostrzeżeń, protestów i oświadczeń, po drugie, może przybrać postać „akcji konfliktowej”, tożsamej z zawieszeniem lub zerwaniem stosunków dyplomatycznych czy demonstracją siły ${ }^{24}$. Akcje

23 Por. W. Malendowski, Spory i konflikty międzynarodowe, w: Międzynarodowe..., s. 357; E. Cziomer, L. W. Zyblikiewicz, Zarys współczesnych stosunków międzynarodowych, Warszawa-Kraków 2000, s. 204.

24 Por. Leksykon wspótczesnych międzynarodowych stosunków politycznych, pod. red. Cz. Mojsiewicza, Wrocław 1996, s. 174. 
konfliktowe, w których przekroczona została granica użycia siły, przeistaczają konflikt międzynarodowy w konflikt zbrojny ${ }^{25}$. Dyferencja między kategoriami „konflikt międzynarodowy” i „konflikt zbrojny” uzasadniana jest względami wykorzystanych środków militarnych lub ich pominięcia. Ponadto w przypadku konfliktu zbrojnego, mamy do czynienia z szeregiem cech szczególnych, ułatwiających kwalifikację omawianego zjawiska. Wskazując cechy właściwe konfliktom zbrojnym, należałoby wymienić, m.in.:

- fakt istnienia minimum dwóch podmiotów wojujących;

- wykorzystanie zorganizowanych sił zbrojnych jednej strony, przeciwko siłom zbrojnym drugiej strony;

- wreszcie, zastosowanie środków i metod walki zbrojnej ${ }^{26}$.

Synonimem pojęcia „konflikt zbrojny” jest termin ,wojna”. Historycznie starszy, nie jest zjawiskiem jednoznacznie definiowanym. Taki stan rzeczy stanowi konsekwencję zmian w technice wojennej i sposobów ich postrzegania na przestrzeni wieków. Pierwotnie ius ad bellum, traktowane było za pochodną suwerenności i stanowiło przyrodzone prawo każdego państwa. Apologeci wojny, traktowali ją za formę działania politycznego, nadając jej walor kreatywnego tworzenia nowych, sprzyjających okoliczności ${ }^{27}$. Hegemonicznej dominacji pozytywnego traktowania wojen, towarzyszył początkowo skromny nurt krytyki. Negacja wojen była pochodną uznania wszelkich zjawisk, związanych z wykorzystaniem siły zbrojnej, za sytuacje niemoralne i godzące w wolność jednostki ${ }^{28}$. Obok całkowitej negacji wojny, kształtował się również prąd wartościujący wojny. Obok odrzucanej bellum iniustum (wojny niesprawiedliwej), dopuszczano istnienie bellum iustum (wojny sprawiedliwej), warunkowanej imperatywem moralnym oraz kryterium sprawiedliwości ${ }^{29}$. Efektem rozróżnienia było zakwalifikowanie wojen, np. obronnych czy narodowowyzwoleńczych, jako wojen sprawiedliwych, natomiast wojen zaborczych do grupy wojen niesprawiedliwych, agresywnych ${ }^{30}$. Kwalifikacja

25 R. Artymiak, Wojny i konflikty w XX wieku, w: Konflikty współczesnego świata, pod. red. R. Borkowskiego, Kraków 2001, s. 39.

26 T. Leśko, Międzynarodowe prawo konfliktów zbrojnych, Warszawa 1984, s. 13.

27 Por. prace T. Hobbesa, N. Machiavellego, H. Grocjusza, F. Nietzschego, C. von Clausevitza i innych.

28 Por. Leksykon politologii, op. cit., s. 437-439.

29 Właściwe m.in. dla doktryny chrześcijańskiej i zwolenników szkoły prawa naturalnego.

30 Zgodnie $\mathrm{z}$ doktryną marksistowsko-leninowską. 
moralna, z gruntu subiektywna, niosła i nadal niesie niebezpieczeństwo relatywnego pojmowania przesłanek, determinujących użycie siły zbrojnej. Z drugiej strony, skrajny pacyfizm grozi niemożnością zastosowania środków koniecznych do obrony własnej suwerenności.

Na przestrzeni dziejów wojny ewoluowały i to zarówno na płaszczyźnie rozważań praktycznych, jak również doktrynalnych. Dwudziesty wiek zmienił obraz wojen, rozumianych wyłącznie w kategoriach faktycznej walki orężnej między państwami. Współcześnie wojny postrzegane są przez pryzmat działań wojennych, oznaczających określone akcje militarne, lądowe, morskie lub powietrzne, przy wykorzystaniu metod konwencjonalnych, partyzanckich, bądź też z użyciem arsenałów broni masowego rażenia, tzw. broni ABC (A - atomowej/jądrowej, B - bakteriologicznej/biologicznej, $\mathrm{C}$ - chemicznej $)^{31}$. Pojęcie wojny zawiera również kategorię „stanu wojny”, oznaczającego istnienie określonego stanu prawnego, trwającego od początku do końca wojny. Powstanie stanu wojny jest powodem natychmiastowego zerwania stosunków dyplomatycznych i konsularnych ${ }^{32}$. Brak stanu wojny, będący następstwem braku formalnego wypowiedzenia wojny, oddala ów automatyzm i uzależnia zerwanie stosunków dwustronnych od woli zainteresowanych podmiotów. Stan wojny nie jest tożsamy z użyciem siły zbrojnej. Istnieniu stanu wojny mogą, lecz nie muszą, towarzyszyć działania wojenne. Argumentem wystarczającym, obok uwarunkowań formalnych, jest możliwość stosowania groźby użycia siły i rzeczywista gotowość do jej użycia.

Dwudziesty wiek przyniósł znamienne przeobrażenia w materii badań nad pokojem i wojną, traktowanych jako stany wzajemnie się wykluczające. Alternatywne pojmowanie tych dwóch zjawisk, doprowadziło do ukształtowania się dwóch prądów badawczych, diametralnie różnych w materii celów, jak i potrzeb badawczych. Bouthoulowska polemologia, stopniowo ustępowała pod naporem badań nad pokojem (peace research). Definiowanie pokoju w kategoriach braku stanu wojny i poszukiwanie poddających się generalizacji, przyczyn i cech znamionujących wojnę, traciło na znaczeniu, oddając prymat warunkom koniecznym dla istnienia i zachowania pokojowego charakteru stosunków międzynarodowych. Powyższa tendencja była następstwem, jak również przesłanką, uregulowań traktatowych w obrębie ius belli (prawa wojen), które delegalizując ius ad

31 Leksykon współczesnych..., s. 340.

32 J. Sutor, Prawo dyplomatyczne i konsularne, Warszawa 2000, s. 160-161. 
bellum, przyniosło szybki rozwój ius contra bellum (prawa przeciwko wojnie). Pokój nie jest jednak stanem permanentnym, bowiem społeczności międzynarodowej, mimo podejmowanych wysiłków, nie powiodło się definitywne wyeliminowanie wojen. Wymogiem konieczności stało się stworzenie norm w zakresie ius in bellum (prawa w wojnie). Powyższe podyktowane było względami głównie humanitarnymi, które od drugiej połowy XIX wieku, zdobywały znaczące miejsce w badaniach nad wojną. Dlatego analizując ius contra bellum i ius in bellum, zyskuje się przeświadczenie, iż niewiele mają one wspólnego z klasycznie pojmowaną polemologią.

Pierwszą próbą ograniczenia siły zbrojnej, jako środka realizacji polityki państw, była Konwencja o pokojowym załatwianiu sporów międzynarodowych, przyjęta podczas drugiej Konferencji Pokojowej w Hadze, 18 października 1907 roku $^{33}$. Dokument ten, nazywany również Konwencją Drago-Portera, w art. 1 stanowi, o ,zapobieganiu, w granicach możliwości, uciekaniu się do siły w stosunkach pomiędzy Państwami”. Nie należy przeceniać tejże Konwencji, gdyż zawarte w niej regulacje, praktycznie nie ,pozbawiały państwa dyskrecjonalnych uprawnień do użycia siły w celu wyegzekwowania przestrzegania prawa międzynarodowego" 34 . Kolejnym etapem na drodze do delegalizacji ius ad bellum był Pakt $\mathrm{LN}^{35}$. Nie zakazywał on bezwzględnie wojny, a jedynie wskazywał procedury załatwiania sporów między państwami (art. 12-15), które miały charakter pierwszorzędny względem innych środków, w tym militarnych ${ }^{36}$. Pierwszą regulację, wyraźnie potępiającą uciekanie się do wojny, stanowił Traktat przeciwwojenny, nazywany również Paktem Brianda-Kellogga ${ }^{37}$. Podpisana 27 sierpnia 1928 roku umowa paryska, w art. 1, stwierdzała, że układające się strony ,potępiają uciekanie się do wojny celem załatwiania sporów międzynarodowych i wyrzekają się jej jako narzędzia polityki narodowej w swych wzajemnych stosunkach”.

33 Dz. U. 1930, Nr 9, poz. 64.

34 Cyt. za: W. Czapliński, A. Wyrozumska, Prawo międzynarodowe publiczne. Zagadnienia systemowe, Warszawa 1999, s. 483.

35 „League of Nations. Official Journal” 1 (1920), s. 11.

36 W. Czapliński, A. Wyrozumska, op. cit., s. 483.

37 League of Nations Treaty Series (dalej LNTS) 94, s. 64; Dz. U. 1929, Nr 63, poz. 489 i 400; przedruk (bez wyliczenia pierwotnych sygnatariuszy), m.in. w: K. Kocot, K. Wolfke, Wybór dokumentów do nauki prawa międzynarodowego, Warszawa 1978, s. 307-308. 
Był to krok milowy na drodze do marginalizacji wojen w stosunkach międzynarodowych, mimo, iż nie dawał on definicji tego zjawiska, jak również nie stwarzał procedur dopuszczających sankcje w przypadku naruszenia wspomnianego zakazu. Próbą wyeliminowania wszelkich mankamentów wcześniejszych unormowań była Karta NZ, która termin wojna zastąpiła pojęciem siły (w domyśle zbrojnej). Art. 2 pkt. 4, wyraźnie precyzuje, że: „Wszyscy członkowie powstrzymają się w swych stosunkach międzynarodowych od stosowania groźby lub użycia siły przeciwko całości terytorialnej lub niepodległości któregokolwiek". Dopuszczalność groźby lub użycia siły w Karcie NZ, uzależniona została od zgodności takiego działania z celami ONZ, bądź jej braku. Tym samym zakaz nie ma charakteru bezwzględnego, gdyż w art. 51, mowa jest o prawie do obrony indywidualnej lub zbiorowej państwa, które padło ofiarą napaści ${ }^{38}$.

Pobieżna refleksja nad naturą współczesnych naukowych poszukiwań i prawnych regulacji w dziedzinie ius belli, dowodzi, że w przeważającej mierze, dotyczą one konfliktów zbrojnych, aniżeli samych wojen. Związana $\mathrm{z}$ tym tendencja odchodzenia od terminu ,prawo wojenne” i zastępowanie go pojęciem ,prawa konfliktów zbrojnych” wynika z pojemności tej drugiej kategorii. Konflikt zbrojny jest zjawiskiem „szerszym” niż wojna, pozwalającym na głębszą analizę złożoności użycia siły zbrojnej w stosunkach międzynarodowych. Wojna charakteryzuje stan relacji wyłącznie między państwami, tymczasem konflikt zbrojny może angażować państwa, jak i innych uczestników stosunków międzynarodowych. Elementem wspólnym, właściwym obu wspomnianym sytuacjom jest siła. Sam fakt podobieństwa nie umniejsza jednak różnic, które pośrednio doprowadziły do traktatowych prób uzupełnienia niedoskonałości terminu wojna. Potwierdzenie trendu rozszerzania norm prawa międzynarodowego na konflikty zbrojne znaleźć można, m.in. w Konwencjach genewskich z 1949 roku, które we wspólnym dla nich wszystkich art. 2, stwierdzają swoją właściwość „W razie wypowiedzenia wojny lub powstania jakiegokolwiek konfliktu zbrojnego między dwoma lub więcej stronami, nawet gdyby jedna $\mathrm{z}$ nich nie uznała stanu wojny"39.

38 W. Czapliński, A. Wyrozumska, op. cit., s. 486.

39 Cyt. za: R. Bierzanek, Stan i perspektywy rozwoju międzynarodowego prawa konfliktów zbrojnych, „Sprawy Międzynarodowe” 1986, z. 4, s. 80. Mowa o czterech Konwencjach prawa humanitarnego, przyjętych 12 sierpnia 1949 r. w Genewie: I Konwencja o polepszaniu losu rannych i chorych w armiach czynnych (United Nations Treaty Series - dalej UNTS 75, s. 31); II Konwencja o polepszaniu losu rannych, 
Literatura przedmiotu skupiona jest również na elementach wspólnych, zjawiska wojny i konfliktu zbrojnego. Niekiedy rozważania definicyjne, są próbą wyjaśniania pojęcia wojny poprzez konflikt zbrojny i odwrotnie. Przykładem powyższego są koncepcje Istvana Kende, popierane $\mathrm{w}$ gronie polskich badaczy przez Zbigniewa Cesarza, a wskazujące trzy zasadnicze cechy wojny rozumianej jako konflikt zbrojny ${ }^{40}$. Wojna w rozumieniu węgierskiego profesora to gwałtowny konflikt masowy, w którym: po pierwsze - występują, dwie lub więcej, zorganizowane siły zbrojne i minimum po jednej ze stron, regularne oddziały wojskowe, biorące udział w walce; po drugie - zaangażowane strony zorganizowane są według określonego schematu oraz istnieje zaplanowana struktura działań zbrojnych; po trzecie - występują centra dowodzenia i ustalona chronologicznie kontynuacja konfliktu zbrojnego bądź korelacja strategicznych i taktycznych zamierzeń szczebla dowodzenia ${ }^{41}$.

Powyższe uwagi nie budzą większych zastrzeżeń, stwarzając dogodną możliwość odróżniania konfliktów zbrojnych od innych metod wykorzystania siły zbrojnej. Definiowanie wojny przez konflikt zbrojny nie jest jednak w pełni uzasadnione. O ile bowiem sam przebieg konfliktu zbrojnego i wojny może być identyczny, to stan formalny zasadniczo różni te dwie formy użycia siły.

Ostatnim pojęciem, wymagającym omówienia jest kryzys w stosunkach międzynarodowych.

Podobnie jak poprzednio wskazane zjawiska, również kryzys (od greckiego słowa krisis i łacińskiego crisis - przesilenie, przełom) jest sytuacją właściwą wszelkim stosunkom społecznym, w tym również stosunkom międzynarodowym.

Umiejscowienie refleksji nad kryzysem międzynarodowym, za rozważaniami na temat wojny, stanowi odstępstwo od przyjętej formuły gradacji sprzeczności. Zabieg ten podyktowany jest trudnościami klasyfikacyjnymi i różnorodnością interpretacji omawianej materii. Zasadnicza przyczy-

chorych i rozbitków - członków sił zbrojnych na morzu (UNTS 75, s. 85); III Konwencja o traktowaniu jeńców wojennych (UNTS 75, s. 135); IV Konwencja o ochronie ludności cywilnej w czasie wojny (UNTS 75, s. 287); przekład urzędowy konwencji: Dz. U. 1956, Nr 38, poz. 171 i 174.

${ }^{40}$ Z. Cesarz, E. Stadtmüller, Problemy polityczne współczesnego świata, Wrocław 2002, s. 76-77.

${ }^{41}$ I. Kende, Über Kriege seit 1945, w: Friedens - und Konfliktforschung, Baden-Baden 1982, s. 121-123. 
na tkwi jednak w braku uregulowań prawnych, dosłownie traktujących termin kryzys.

Napięcie w stosunkach międzynarodowych jest wprost proporcjonalne do poziomu sprzeczności międzynarodowych. Wzrost napięcia, będący konsekwencją rozwoju sprzeczności, prowadzi do sytuacji kryzysowych. Przechodzenie sprzeczności w stan kryzysu, jest równoznaczne z deformacją istniejących stosunków międzynarodowych i tożsame ze zmianą status quo ${ }^{42}$. Co więcej, oznacza dyskredytację arsenału środków koniecznych dla ograniczenia lub zażegnania napięcia. Rezygnacja z mechanizmów kontroli eskalacji napięcia jest dowodem ich nieefektywności, lecz przede wszystkim kwintesencją braku woli kompromisu. Kryzys stanowi zatem najwyższą formę zaostrzania się sprzeczności i wiąże się z radykalnym ograniczeniem stosunków zaangażowanych stron ${ }^{43}$. Nowa formuła owych stosunków ma charakter sporadyczny i nie ma konstruktywnego wpływu na próby przywrócenia status quo ante lub stworzenia nowej, pozbawionej sprzeczności i napięć, jakości w relacjach zainteresowanych podmiotów. Powyższe stanowi następstwo, niekoniecznie świadomych decyzji głównych aktorów, lecz gwałtownego i nieoczekiwanego rozwoju sytuacji oraz stopniowego ograniczania dopływu informacji do organów decyzyjnych.

Zmiana istniejącego stanu rzeczy, nie jest jednak bezwzględnie koniecznym aspektem wystąpienia kryzysu. Kryzys w zależności od punktu widzenia i metodologii badań, dla jednych badaczy może oznaczać każdorazowo radykalną zmianę, dla innych może również dopuszczać przywrócenie poprzedniego stanu rzeczy ${ }^{44}$. Niezależnie od sytuacji końcowej, każdy kryzys pozostawia ślad na stosunkach międzynarodowych tym silniejszy, im intensywniejsze były bodźce, a zdolność przywrócenia równowagi ograniczona. Kryzys międzynarodowy jest pojęciem nieostrym i bywa definiowany, bądź w charakterze stadium konfliktu lub sporu międzynarodowego, bądź jako forma odrębna użycia siły zbrojnej. Postrzega-

42 Por. S. Klimkiewicz, Kryzys w stosunkach międzynarodowych i odprężenie, „Sprawy Międzynarodowe” 1978, z. 12, s. 114 i n.

43 J. Kukułka, Zaspokajanie potrzeb i rozwiazywanie konfliktów w stosunkach międzynarodowych, w: Stosunki..., s. 247.

44 Szerzej na temat definiowania kryzysów międzynarodowych w: S. Klimkiewicz, Teoretyczne aspekty rozwiazywania kryzysów międzynarodowych, „Sprawy Międzynarodowe" 1976, z. 10, s. 118-124. 
ny jest również, nie tylko jako kulminacyjny etap konfliktu, ale stan pośredni między pokojem i wojną ${ }^{45}$.

Przykładem teoretycznej refleksji nad istotą omawianego zjawiska, są propozycje Hermana Khana, dla którego kryzys oznacza:

„1)punkt zwrotny w sekwencji wydarzeń;

2) sytuację, która wymaga podjęcia szybkich decyzji;

3) stanowi zagrożenie dla celów i planów zaangażowanych podmiotów;

4) konsekwencje mające zwykle poważne znaczenie, w dużym stopniu determinujące przyszłość zaangażowanych podmiotów;

5) konwergencję wydarzeń i przypadków, których wzajemne oddziaływanie i połączenie prowadzi w konsekwencji do powstania nowych jakościowo zjawisk;

6) okres, w którym gwałtownie wzrasta stopień niepewności co do trafności oceny sytuacji i wyboru kierunku działania przy jednoczesnym spadku efektywności kontroli nad wydarzeniami i zrodzonymi przez nie skutkami;

7) charakteryzuje się pośpiechem, presją wydarzeń, krótkimi okresami dla podjęcia niezbędnych i ważnych decyzji oraz napięciem towarzyszącym wszystkim partnerom;

8) cechuje się zwykle niedostatkiem informacji o pełnym cyklu wydarzeń oraz zmianą charakteru stosunków między podmiotami"46.

Koncepcje H. Khana nie budzą zastrzeżeń metodologicznych, dając satysfakcjonujące źródło wiedzy o sytuacjach, które zwykliśmy określać mianem kryzysów.

Podsumowując, można stwierdzić, iż kryzys jest momentem zwrotnym, przesileniem $\mathrm{w}$ fazie napięcia międzynarodowego, niosącym potencjalną zmianę $^{47}$. Oznacza brak równowagi między zainteresowanymi aktorami, będący przeszkodą w procesie komunikacji dwustronnej. Niemożność wymiany informacji grozi eskalacją napięcia i odwołaniem się do argumentacji siłowej. Kryzys jest domeną konfliktów międzynarodowych i utożsamia stadium charakteryzujące się koniecznością podejmowania szybkich decyzji. Znajomość przeciwnika nie jest argumentem wystarczającym dla zdobycia przewagi, gdyż równie istotne są zdolności zespołu decyzyjnego. Wypada zatem zgodzić się z twierdzeniem, że kryzys jest momentem kulminacyjnym w konflikcie międzynarodowym.

\footnotetext{
45 Por. L. Pastusiak, Komputery a polityka, Warszawa 1975, s. 108-110.

46 Cyt. za: ibidem, s. 117-118.

47 Por. Leksykon politologii, op. cit., s. 181.
} 
Pobieżna prezentacja podstawowych zagrożeń, dla pokoju i bezpieczeństwa międzynarodowego, nie jest kompletna. Pozwala jednak na zaakcentowanie sytuacji kluczowych, charakterystycznych dla stosunków międzynarodowych. Zaprezentowane formy stosunków, są wyrazem działań i oddziaływań międzypaństwowych, dynamizujących cały system międzynarodowy, jak i poszczególne podmioty prawno-międzynarodowe. Proces aktywizacji działań warunkuje nie tylko sferę stosunków międzynarodowych, lecz również ma wpływ na sytuację wewnętrzną, głównych aktorów. Niezależnie od tego czy mamy do czynienia ze stanami patologicznymi czy sytuacjami normalnymi. Różnorodność tych zjawisk determinuje konieczność analizowania ich na tle pozostałych. Stanowi to przesłankę ułatwiającą rozważania klasyfikacyjne oraz dostrzeżenie istoty każdej $\mathrm{z}$ przedstawionych form.

\section{Summary}

Current international relations are a forum for an incessant articulation of needs and interests. This process results from progressing globalization and the actual disappearance of the borders of information exchange. Every form of activity of a given international subject, or their group, shall not remain overlooked by the remaining participants of international relations, irregardless of the distance between them. Therefore, all international subjects whether primary or secondary, who undertake certain activities are aware of exerting a simultaneous influence on the remaining elements of the international system.

Therefore, ,presence" on an international arena is not static but it is a dynamic process stimulated by a chain of actions and reactions by particular subjects. In the era of globalization the matter of security and threats for security assumes particular importance. Increased interdependence determines the necessity to create a stable system of controls to prevent the threat of a global war or a military conflict. Therefore, it is of utmost importance to be aware of the processes of contradiction escalation and the ability to react appropriately in case discomforting phenomena are identified. This is impossible unless the definitions and the essence of contradiction, dispute, conflict, crisis, war and military conflict are known. The notion analysis that concentrates on the treaty stipulations prompts to expand the research of differences between the above notions. Primarily, though, it emphatically condemns the shameful practice of applying these notions interchangeably, as if equivalent, both in popular articles and in research papers. 